\title{
Correction to: Breast Implant-Associated Anaplastic Large Cell Lymphoma (BIA-ALCL) and the Textured Breast Implant Crisis
}

\author{
Anne K. Groth ${ }^{1,2,3,4} \mathbb{1} \cdot$ Ruth Graf $^{1,5,6}$
}

Published online: 5 May 2020

(C) Springer Science+Business Media, LLC, part of Springer Nature and International Society of Aesthetic Plastic Surgery 2020

Correction to: Aesth Plast Surg (2020) 44:1-12. https://doi.org/10.1007/s00266-019-01521-3

Anne K. Groth's name was wrongly tagged in the original publication of this article. It has been corrected here.
Publisher's Note Springer Nature remains neutral with regard to jurisdictional claims in published maps and institutional affiliations.

The original article can be found online at https://doi.org/10.1007/ s00266-019-01521-3.

Anne K. Groth

annegroth@gmail.com

1 Brazilian Society of Plastic Surgery, Curitiba, Brazil

2 Plastic Surgery and Microsurgery Department, Erasto

Gaertner Hospital, Curitiba, PR, Brazil

3 Positivo University Medical School, Curitiba, Brazil

4 Curitiba, Brazil

5 Federal University of Parana, Curitiba, Brazil

6 Pieta Medical Center, Rua Solimões 1175, Curitiba, PR, Brazil 